\title{
Flavor Development in Various Forms of Cheese
}

\author{
Rida Malik*, Maria Tahir, Nida Pervaiz and Sikander Ali \\ Institute of Industrial Biotechnology, Government collage university Lahore, Pakistan \\ *Corresponding author
}

\begin{tabular}{|l|}
\hline Ke y w o r d s \\
Cheese, Microflora, \\
Flavor, Ripening \\
\hline Article Info \\
\hline $\begin{array}{l}\text { Accepted: } \\
22 \text { December } 2019 \\
\text { Available Online: } \\
\text { 20 January } 2020\end{array}$ \\
\hline
\end{tabular}

\section{Keywords}

Cheese, Microflora, Favor, Ripening

Accepted:

22 December 2019

20 January 2020

\section{A B S T R A C T}

Though the cheese production through the curd milk is the oldest science, the fermentation technology unfurled the cheese production many thousand years ago and by now cheese is available in hundreds of different types and flavors from different climatic and environmental region. Availability of cheese in different flavors is mainly due to the origin/ source of milk and whether the milk is pasteurized and the butter content of the milk. The interplay of different microflora, physical and chemical conditions play role in production of various flavor types. Microorganisms growth is essential in development of flavor and true microflora growth is determined by the regulation of moisture and salt content, $\mathrm{pH}$ regulation, organic acid concentration, maintenance of ripening temperature, regulation of redox potential and also on nitrate production. Proteolysis and lipolysis also play an important role in flavor enhancement. If the ripening procedure goes haphazardly then there will be more chances of rancidity but our understanding of cheese ripening process and parameters will reduce the cost and time, energy and material consumption and also efficiently increase the production of variety of cheese. In this review, we had reviewed different parameters and their interplay for the successful cheese ripening and the better taste to provide.

\section{Introduction}

Though food fermentation that is the oldest biotechnology, man can enjoy improved flavors, texture, shelf life and other health benefits of fermented products including sauerkraut, pickles, bread, bear, yogurt, sausages, cheese etc. by enzymatic and microbial processing (Giraffa, 2004).It's about the ancient era 8000 years ago, the dairy product, Cheese, making worldwide with unique flavors and forms and originated through transportation of milk in bladders made of ruminants' stomachs due to their inherent supply of rennet, which is the agent for the conversion of milk into curd (solid i.e. cheese) and whey (liquid).Different flavors are produced by different species of animals and it is thought that after cheese formation, the flavor becomes more intense day by day (Adda et al., 1982) because of bacterial activity on the curd and it was not analyzed 
till the $19^{\text {th }}$ century. Gorgonzola was first taken into account in $\mathrm{AD} 879$, Roquefort in 1070 and cheddar in 1500.Cheese (fig. 1), a highly nutritious food, is a dairy fermented product constituting proteins and fats formed by coagulation of milk protein casein available in various flavors and textures throughout the world. Three parts of world milk production is used in cheese production, and over more than thousand cheese varieties are there in the world.

Fermentation is very important technology, unfurled the cheese production many thousand years ago. People enjoy various cheese types with different characteristics like texture, flavor, nutrition etc. To study these characteristics, one should focus on cheese microbiology. In cheese microbiology different aspects come in front of

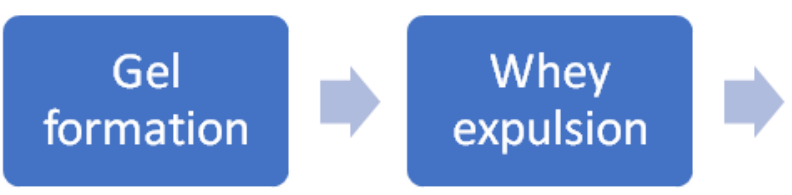

microbiologists including microflora, carbonyl compounds, proline content, nonstarter lactic acid bacteria, lipolysis etc.Greater expertise of biochemists and microbiologists regarding biochemistry and microbiology of cheese refinement technology is creating a diversity in cheese textures and flavors. The microbial, enzymatic and chemical transformation by the breakdown of milk fats, proteins, lactic and citric acid into a variety of volatile and nonvolatile compounds during ripening, are the contributing factors to the cheese flavor and texture. (Adda et al., 1986)Different varieties evolved involving the four integral components that are microorganisms, rennet, milk and salt. These are processed through following steps. (Beresford et al., 2001)

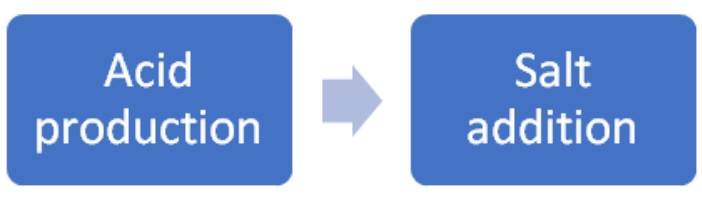

acids. Further after manufacture, the lactate content relates to the lactose amount. According to Langsrud and Reinbold the good quality cheese formed when there are propionic acid, acetic acid and low quantity of higher fatty acids and butyric acids. The flavor of swiss cheese become strong and rancid because of the higher fatty acids and bulk of butyric acid.

Due to proline content swiss cheese gives a specific sweet flavor, which is lesser in other cheese types. Low concentrations of carbonyl compounds arealso important for flavor characteristics in cheese (Langsrud and Reinbold, 2016). Cheese used (NSLAB) to get their palatability which developed during processing. 


\section{Cheddar cheese}

Bitterness in cheddar cheese(Fig.3) is due to peptides. (Broadbent et al., 1998) Prop. Shermanii has slightly sweet and nutty flavor which is probably due to the high activity of peptidases at high level $107 \mathrm{cfu} / \mathrm{mL}$. proteolytic activity is due to the rennet, milk and starter proteinases (visser et al.,1977) There is large difference in the total and individual amino acids which is not the case with Lactobacillus casei, and it is due to the appropriate enzymatic release acting as limiting factor. The increase in amino acids is either due to autolysis or metabolism of viable cells. (El-Soda et al., 1981) It is proposed that the flavor of cheddar cheese is also due to the fat degradation products as it has not exceptionally high specific free fatty acid contents as that of other Romano, Provolone, and Swiss cheese and some of the flavor is also due to the hydrogen sulphide. (Kristoffersen et al., 1960) M. freudenreichii when added during manufacture disappears rapidly yet have an impact on flavor hastening in pasteurized milk but other strains are present in comparatively large amount (Alford et al., 1950).

\section{Iranian Lighvan cheese}

Lighvan cheese (Fig.4) is semi-hard traditional Iranian cheese as Iranian Lighvan cheese raw ewes milk used to overcome the need of Iranian market. Isolated bacteria identified from the homogenized sample using microbiological analysis. Lactic flora produced from NSLAB in large proportion and then selection of colonies done. The characteristic to ferment carbohydrate is specific for isolates, due to which these classified into lactobacillus, pediococcus and enterococcus (46\%, $12 \%$ and 42\%). E. faecium through proteolysis activity on milk proteins and particularly on casein, along with high lipolytic activity, develop flavor characteristics of cheese. (Abdi et al., 2006)(abdi, Sheikh-Zeinoddin and Soleimanian-Zad, 2006)

\section{Blue cheese}

Methyl ketones play an integral part in the flavor of blue cheese. The constituents of blue cheese (fig.5) i.e.pentanone-2, heptanone-2 and nonanone- 2 are obtained from fractional distillation of blue cheese. Acetone (identified as constituent of blue cheese by ether extracted steam distillate of blue cheese) has also the effect on cheese flavor. Betaoxidation of fatty acids results in the formation of methyl ketones and due to these constituents' mold ripened blue cheese has a distinct flavor from other cheese types (Patton et al., 1950)

\section{Mozzarella}

Mozzarella(Fig.6), made from buffalo milk, is a soft, un-ripened cheese of the pasta filata family. Streptoxoccus thermophilus is the starter bacteria for mozzarella cheese and the mozzarella cheese is composed of $23-25 \%$ fat and 50\% moisture. (Jana et al., 2011) The action of lactic acid on dicalcium-paracaseinate is the characteristic feature of mozzarella cheese. Branched short chain free fatty acids have an important role in its palatability and the bitterness is prevented by the reduced amount of rennet. (Micketts et al., 1974) Mozzarella, rennet coagulated cheese undergoes a 3 weeks period of ripening.

\section{Limburger cheese}

Limburger cheese (Fig.7) has a strong complex flavor. It contains large amounts of C4 and C6 free fatty acids but there is no depiction in flavor and this is may be due to its $6.97 \mathrm{pH}$ which due to lower vapor pressure of free fatty acid salts suppresses the flavor expression of free fatty acids. The presence of 
peptides, amines, long chain ketones, free fatty acids play an integral role in extremely bitter flavor of Limburger cheese. (Woo et al., 1984.)

\section{Gouda cheese}

Major microflora during processing and ripening is lactic acid bacteria. Both rennet and proteases have an integral role for the bitterness in gouda cheese (Fig.8). Peptidases have an integral part in the formation of bitter peptides and also in the removal of bitter peptides once they are formed. Bitterness may also increase by increase in y-caseins level and this the due to imbalance hydrolyzation of milk casein. (Habibi- Najafi et al.,1996)

\section{Camembert cheese}

Camembert (Fig. 9) is a mold ripened cheese. Methyl ketones, alcohols, 2-phenylethanol and sulfur compounds are involved in aroma and flavor of the camembert cheese but it is still unknown that which compound is more important in its aroma and flavor. (Molimard et al., 1996.)

\section{Chevre cheese}

More than 80 compounds are involved in composition of Chevre style goat cheese(Fig.no.10). Thirteen fatty acids have considerable importance due to their efficient rate of lipolysis and also due to their sweet flavor contribution. Specific goat flavor has been contributed by Octanoic, 4methyloctanoic and 4-ethyloctanoic acids and are present in moderate concentrations and it has been characterized as sweet, rancid, fatty with medium intensity.( Sánchez-Palomo et al., 2008) Sweet aroma and milk fat flavor has been also characterized by several gamma lactones.( Whetstine et al.,2003) By decreasing sharpness imparted by fatty acids and bitterness imparted by amines, most esters produce floral and fruity flavor. (Anderson et al., 1966) Toasty flavor is imparted by furan compounds at low concentration (Sánchez-Palomo et al., 2008)

\section{Monterey jack cheese}

Monterey jack(fig.no.11) is obtained from cow with $32.7 \%$ fat and $41.4 \%$ moisture. (Heisserer et al., 1993). It has a milky flavor with slight sweet and slight bitter taste lacking fatty acid and ester flavor and contains very low volatile free fatty acids. (Ha et al., 1991)

\section{Determinants of growth of microorganisms in cheese}

\section{Moisture}

As microorganisms tend to grow in presence of moisture, susceptibility to spoilage increases with increased moisture content and to reduce the susceptibility of spoilage moisture content is reduced either by dehydration or by the incorporation of watersoluble compounds. Water activity is a thermodynamic property, directly related to moisture content and inversely related to the concentration of salt and other low molecular weight compounds (Esteban et al., 1989.) During the gel formation, a cheese manufacturing step, the water activity level is highest i.e. 0.99 to promote growth of microorganism and relatively decreases in the upcoming stages i.e. whey expulsion, salting and during ripening and are significantly lower (0.917-0.988) than the requirement of starter culture bacteria. (R. uegget al., 1981.) Water activity values of different bacteria are given in Table 1

\section{Salt}

Salt and moisture content are associated to each other as salts reduce moisture and hence inhibit starter and spoilage bacteria. But many 
organisms are growing even at high salt concentration and low moisture level, which means they are capable to grow in such environments and it also suggests that there are many interacting factors to inhibit unnecessary growth of microorganism which would lead to spoilage and hence bad flavor and texture. The salt concentration relies on the nature of food, $\mathrm{pH}$ and its moisture contents. Corresponding to water activity values $0.97-0.99$, the salt concentration ranges between 0.7 to $7 \mathrm{~g} / 100 \mathrm{~g}$.

\section{pH and organic acids}

Neutral $\mathrm{pH}$ is favorable for the growth of most typical microorganisms and at $\mathrm{pH}$ less than 5 the growth of most microorganisms is poor as there are more acid sensitive bacteria present in most of the environment. Due to the accumulation of organic acids, cheese curd has a pH between 4.5 and 5.3 and acid sensitive bacteria cannot survive these harsh conditions. Lactic acid, acetic acid and propionic acid are the most common acids found in cheese, depending on their $\mathrm{pKa}$ value the lactic acid is least inhibitor and propionic acid is the most effective inhibitor at the same $\mathrm{pH}$ value. $\mathrm{pKa}$ values of different organic acids are given in table no. 2

Except swiss cheese in which Propionic acid is higher in content than lactic acid, all other varieties have higher content of lactic acid. (Steffen et al., 1993.)

\section{Ripening temperature}

Ripening temperature is the balance between the requisite to enhance ripening reactions, the consideration of desirable secondary flora and the inhibition of spoilage due to over ripening, as higher temperatures increase ripening (Folkertsma et al., 1996) but at the same time are detrimental due to over growth of spoilage bacteria. Mesophiles are most commonly involved in cheese ripening working optimally at $32^{\circ} \mathrm{C}$ and thermophiles working optimally at $42^{\circ} \mathrm{C}$.

\section{Reduction-oxidation potential}

The oxidation-reduction potential (Eh) of milk is $+150 \mathrm{mV}$ while that of cheese is $250 \mathrm{mV}$. It may be mostly due to the reduction of trace amounts of $\mathrm{O} 2$ and also due to fermentation of lactic acid by the starter culture during growth. Eh value may span from about $+300 \mathrm{mV}$ for aerobes which resides within the cheese to less than $-400 \mathrm{mV}$ for anaerobes which resides on the surface of cheese for different microbial cultures and hence Eh also suggest the existence of different microbial flora either within the cheese or on the surface of cheese

\section{Nitrate}

In the production of Dutch-type cheeses, to hinder the growth of clostridium tyrobutyricum, which ferment lactate to butyrate, hydrogen and carbon dioxide, nitrate is added as sodium nitrate (NaNO3) or potassium nitrate (KNO3).

\section{Lactate $=1$ Butyrate $+2 \mathrm{CO} 2+2 \mathrm{H} 2$}

In the Dutch-type cheeses, the rate of $\mathrm{NaCl}$ shift is very low and moisture content is also very high and for this reason nitrate is added to prevent large hole formation as large holes are created by $\mathrm{H} 2$ and $\mathrm{CO} 2$ and also to prevent off-flavor formation by butyrate. The xanthine oxidase present in the curd, reduce the nitrate into nitrite, the actual growth inhibitor. Nitrite inhibit Propionibacterium; thus, nitrate is not used in cheese where Propionibacterium is needed for growth. However, nitrite does not inhibit lactic acid bacteria. Most of the nitrate is detected within the whey and brine and by the time the cheese is ready for consumption, the nitrate level is 
exceptionally beneath the permissible levels i.e. $50 \mathrm{mg} / \mathrm{kg}$ (Beresford et al., 2001)

\section{Microorganism effect on cheese flavor}

\section{Growth of microflora after cheese production}

Taking intervals after maturation for identification of isolates, after 7 days of manufacturing cheese both lactic acid bacteria and Enterobacter increases while after 18 days lactic acid bacteria increases but Enterobacteriaceae may stop.This work gives the confirmation that, during ripening of cheese the evolutionary microflora is quantitatively and qualitatively similar in various types. (Malcata, 1998).

All these components involved in the flavor development of various cheeses. Here we are considering 4 articles of different authors of different times which all discussed the production of lactic acid flora through different means. Malcata1998 and Abdi, Sheikh-Zeinoddin

\section{Starter culture bacteria}

A controlled fermentation is used when the manufacturing's yield is unstable and the chance of pathogenic microbes' growth is present. In this fermentation bacteria are first selected and isolated for the manufacturing and maintained for the use and referred to as starter culture (Giraffa, 2004).

The production of acid is the basic function of the starter culture during fermentation as well as starter culture is also involved in cheese ripening process. Enzymes of the starter bacteria basically convert amino acids into flavor compounds and also contribute in proteolysis process (Fox et al., 1997). In the milk isolates starter bacteria are used which are tend to reduce the $\mathrm{pH}$ of milk. Starter bacteria could be added at initial stages of cheese manufacturing process or these may be found in the milk as natural contaminants as in many cheese varieties that are manufactured using raw milk. within the starting hours of manufacturing the starter culture grow and densities of $108 \mathrm{cfu} / \mathrm{g}$ is maintained. May be thermophilic or mesophilic starter bacteria could be used that depend on the variety of cheese being produced. In Cheddar, Camembert and Blue cheese mesophilic cultures are used while for Parmesan and Emmental cheese thermophilic culture are used.

In mesophilic and thermophilic starter cultures there are of two categories one is mixed or undefined culture and other is known as defined culture. Citrate metabolizing strains of Lactobacillus lactis sp. cremoris and Lactobacillus lactis sp. lactis could be present as undefined culture of mesophilic culture, for the production of flavor (Lodics et al., 1993). Mesophilic cultures are used worldwide for Cheddar cheese manufacturing. Thermophilic starters are composed of strains of Lactobacillus delbrueckii sp. delbrueckii, Lactobacillus delbrueckii sp. lactis, Lactobacillus delbrueckii sp. bulgaricus, or Lactobacillus helveticus. Thermophilic undefined cultures are used for manufacturing of Emmental cheese at small scale in Italy and France.

\section{Non-starter lactic acid bacteria}

Mesophilic pediococci and lactobacilli microbial flora may be present as non-starter lactic acid bacteria during ripening process of various cheese. These NSLAB are not component of the starter flora because their growth is not good in milk and they do not take part in the acid production in manufacturing of cheese (Cogan et al., 1997). Isolated mesophilic lactobacilli species from cheese include lactobacillus casei or 
lactobacillus paracasei, Lactobacillus rhamnosus, lactobacillus plantarum, and lactobacillus`curvatus (Jordan et al., 1993; Coppola et al., 1997; Fitzsimons et al., 1999). WhilePediococcus acidilactici and pentosaceus are more frequent in cheese.

It is obvious that strain selection is very important in the quality of cheese as high quality of cheddar cheese is produced by some strains of lactobacillus casei sp. casei and Lactobacillus casei sp. pseudoplantarum. On the other hand, bitter flavor acid in cheese is due to other strains of these species (Lawrence et al., 1987). During the production of cheddar cheese gas level that is due to inoculated heterofermentative is reduced when heterofermentative lactobacillus is added (Laleye et al.,1990). In cheese NSLAB comes from postpasteurization contamination or strains that survive after pasteurization (Turner et al., 1986; Martley et al., 1993).

\section{Propionic acid bacteria (PAB)}

During cheese ripening of various cheese types propionic acid bacteria grow. The characteristic microflora of most of the cheeses such as Emmental propionic acid bacteria include short rod-shaped grampositive bacteria and they are involved in lactate metabolism (Steff en, 1973). Five species of $\mathrm{PAB}$ are recently recognized that includes Propionibacterium jensenii, Propionibacterium freudenreichii, $P$. acidipropionic, Propionibacterium thoenii, and Propionibacterium cyclohexanicum and one Propionibacterium coccoides proposed (Vorobjeva, 1999). Wild type PAB was present in sufficient amount during manufacturing of cheese from raw milk.

The characteristic flavors of these Swiss-type cheeses is developed from post manufacture propionic acid fermentation. While eye formation in cheese is due to carbon dioxide production. After the enough eyes formation in cheese it is stored at lower temperatures to further cease the metabolism and growth of PAB (Baer, 1995). Infection during the growth in swiss type cheese from bacteriophage $P$. freudenreichii is recently recognized, these infections cause propionic acid bacteria lysis during the cheese ripening process (Gautier et al., 1995). Interactions of other bacteria with propionic acid bacteria during cheese ripening is also important. These stimulatory and inhibitory interaction of propionic acid bacteria with other cheese bacteria impose an important impact on cheese quality and need to be considered in detail.

\section{Yeast}

Yeasts are found in many varieties of cheeses but their workout plan in ripening is unclear.( Fleet et al., 1990)D.hansenii is most commonly found yeast in most variety of cheeses such as weinkase, Roquefort, carables etc. but there are also other important species such as K.lactis, Yarrowia lipolytica and Trichospora beigelii which are also found in different variety of cheeses. Yeast grow optimally under the conditions of high salt levels, low temperature and $\mathrm{pH}$ and low moisture content. At high salt concentrations yeast metabolize the lactate and it grows during the early days of ripening and it will help in deacidification. (Eliskases-Lechner et al., 1995) Yeast play an important role in the development of texture and flavor. Flavor is also enhanced due to lipolysis and deacidification by yeast.

\section{Smear bacteria}

Smear bacteria cheeses are characterized by the presence of smear on the surface of cheese and these cheeses are found in many European countries in large amounts. During 
early phase of ripening, staphylococci are most commonly found but in later stages, they are replaced by Corynebacterium. They are generally in soft or semi-soft variety but there are also few hard cheeses such as Comte. Amino acids and fatty acids produced from the proteinases, peptidase and lipases play role in the flavor of in these types of cheeses.

Table.1 Water activity values of different bacteria(Weber et al.,1987)

\begin{tabular}{|l|l|}
\hline Bacteria & Water activity values \\
\hline Lactococcus lactis & 0.93 \\
\hline Streptococcus thermophilus & 0.98 \\
\hline Lactobacillus helveticus & 0.96 \\
\hline $\begin{array}{l}\text { Propionibacterium } \\
\text { freudenreichii }\end{array}$ & 0.96 \\
\hline
\end{tabular}

Table.2 pKa values of different organic acids involved in cheese manufacture

\begin{tabular}{|l|l|}
\hline $\mathbf{p}$ & pKa value \\
\hline Lactic acid & 3.08 \\
\hline Acetic acid & 4.75 \\
\hline $\begin{array}{l}\text { Propionic } \\
\text { acid }\end{array}$ & 4.85 \\
\hline
\end{tabular}

Table.3 Component effect on growth of microflora

\begin{tabular}{|c|c|c|c|c|c|}
\hline Authors & $\begin{array}{l}\text { Fatty acid } \\
\text { microflora }\end{array}$ & $\begin{array}{l}\text { Proline } \\
\text { content }\end{array}$ & $\begin{array}{l}\text { Carbonyl } \\
\text { compounds }\end{array}$ & NSLAB & Lipolysis \\
\hline $\begin{array}{l}\text { (Langsrud and Reinbold, } \\
\text { 2016) }\end{array}$ & $\sqrt{ }$ & $\sqrt{ }$ & $\sqrt{ }$ & $X$ & $X$ \\
\hline $\begin{array}{l}\text { (Abdi, Sheikh-Zeinoddin } \\
\text { and Soleimanian-Zad, 2006) }\end{array}$ & $\sqrt{ }$ & $\mathrm{X}$ & $\mathrm{X}$ & $\sqrt{ }$ & $\sqrt{ }$ \\
\hline $\begin{array}{l}\text { (Arnold, Shahani and } \\
\text { Dwivedi, 2010) }\end{array}$ & $\sqrt{ }$ & $\mathrm{X}$ & $X$ & $X$ & $\sqrt{ }$ \\
\hline (Malcata, 1998) & $\sqrt{ }$ & $\mathrm{X}$ & $\mathrm{X}$ & $\sqrt{ }$ & $\mathrm{X}$ \\
\hline
\end{tabular}


Fig.1 Various forms of cheese

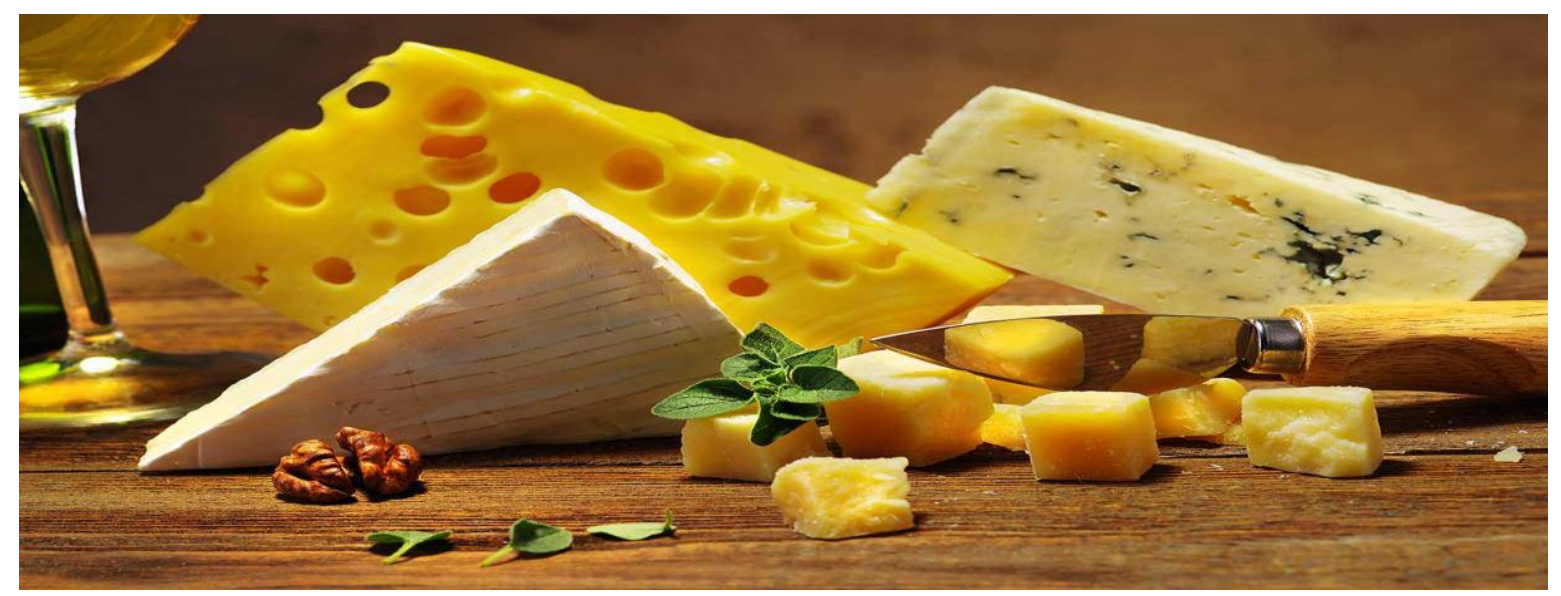

Fig.2 Swiss cheese

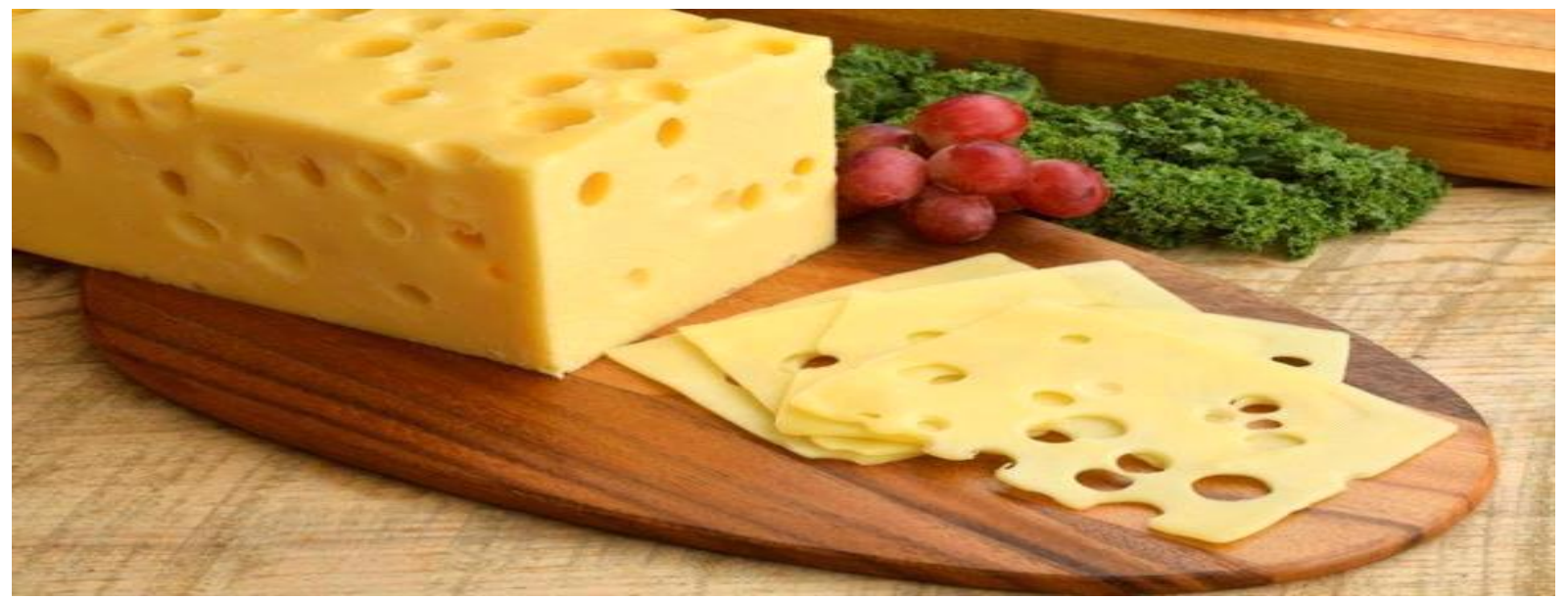

Fig.3 Cheddar cheese

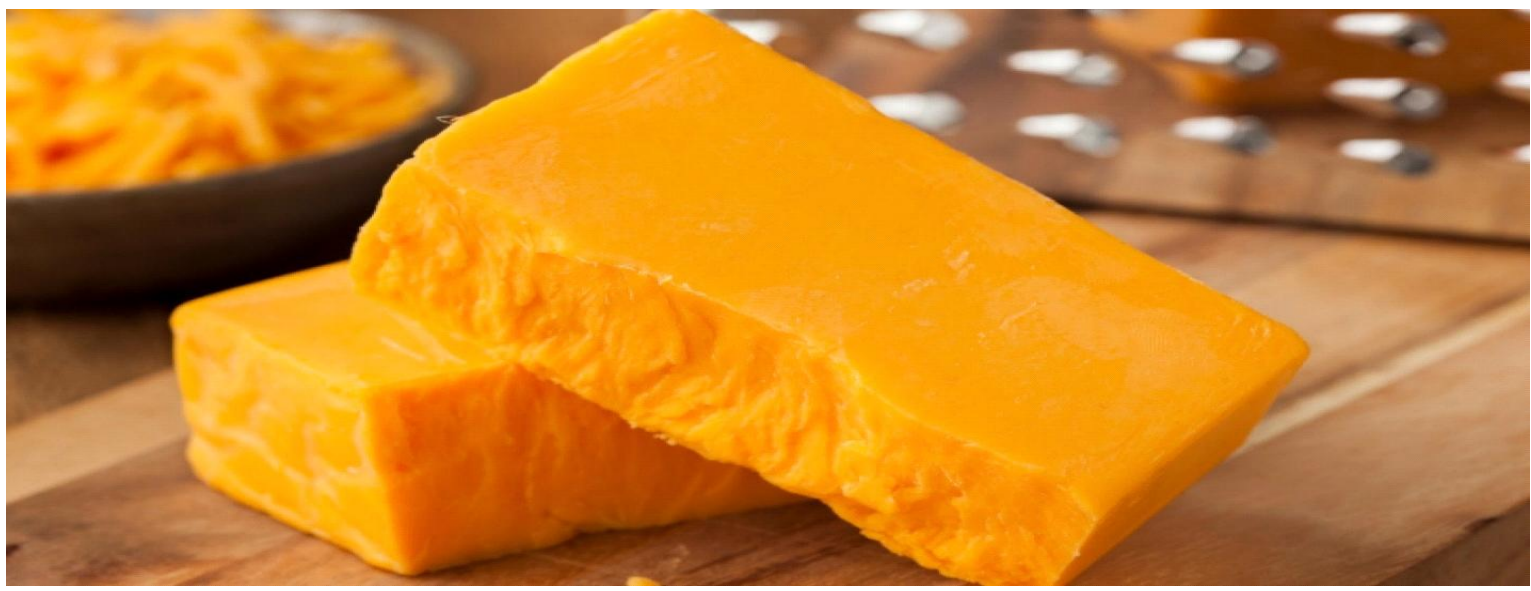


Fig.4 Iranian lighvan cheese

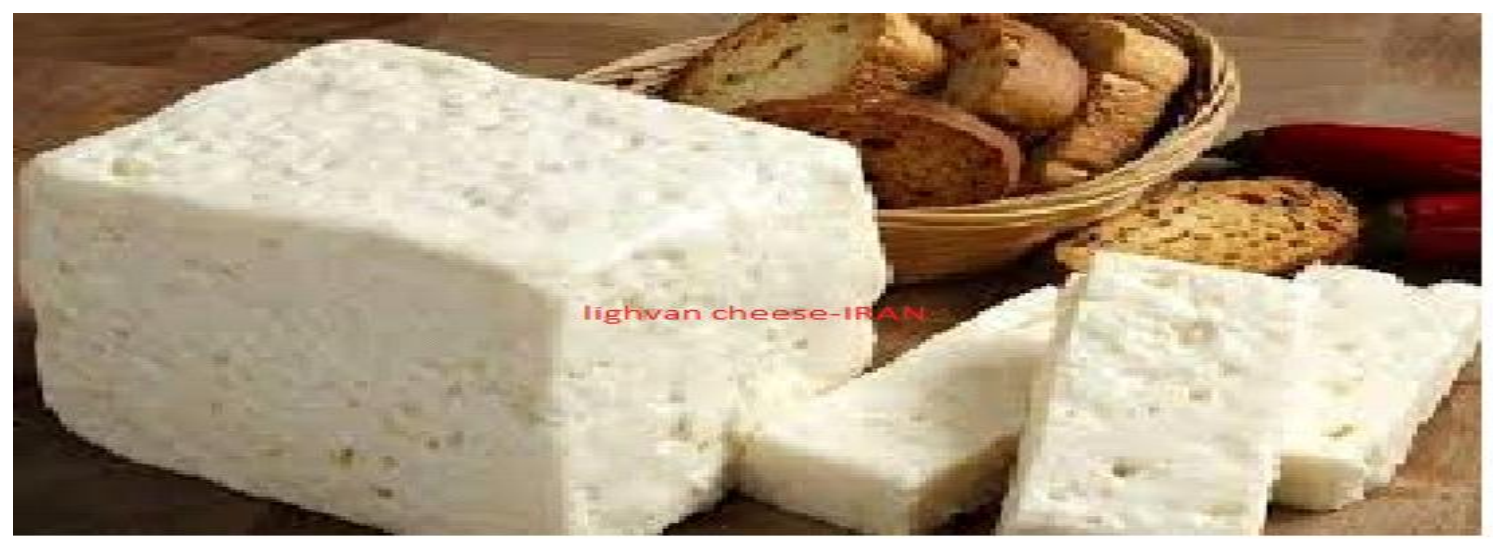

Fig.5 Blue cheese

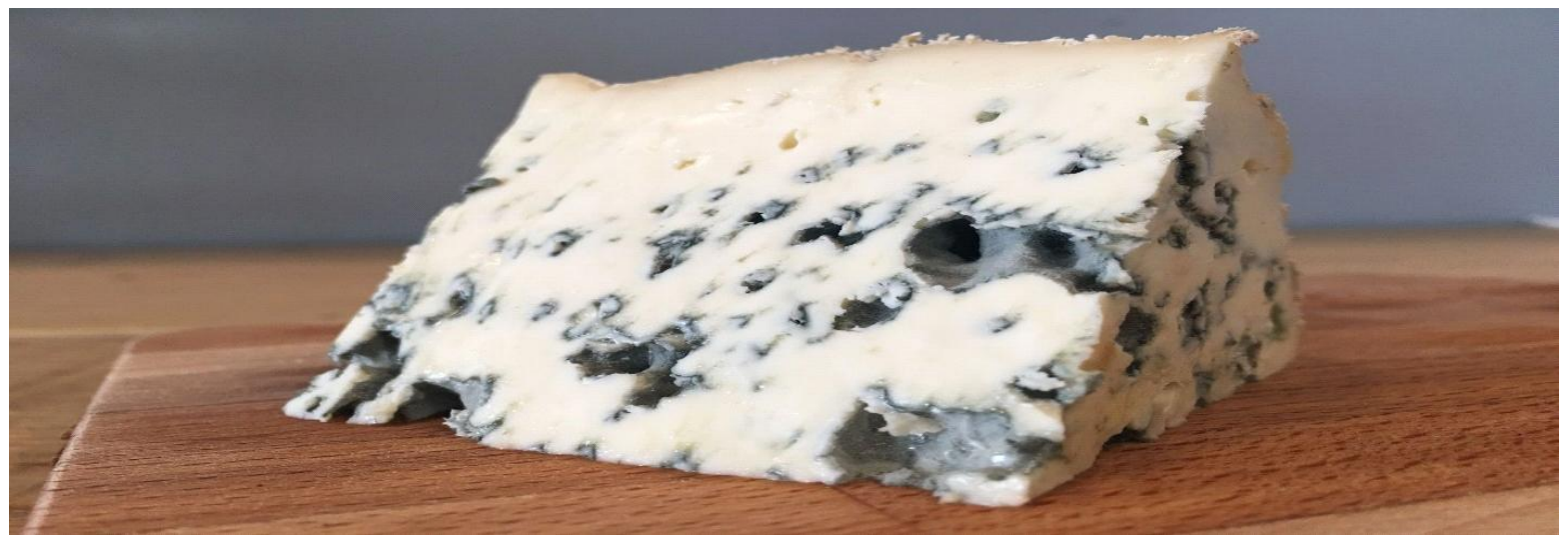

Fig.6 Mozzarella cheese

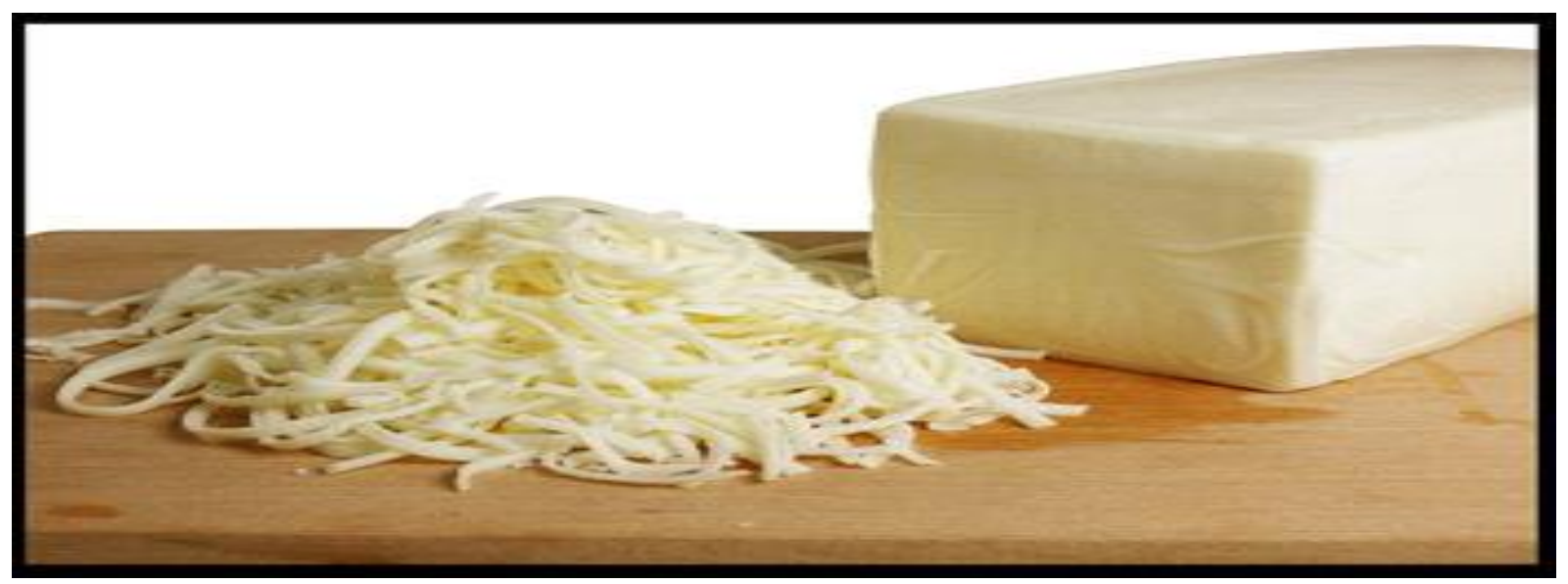


Fig.7 Limburger cheese

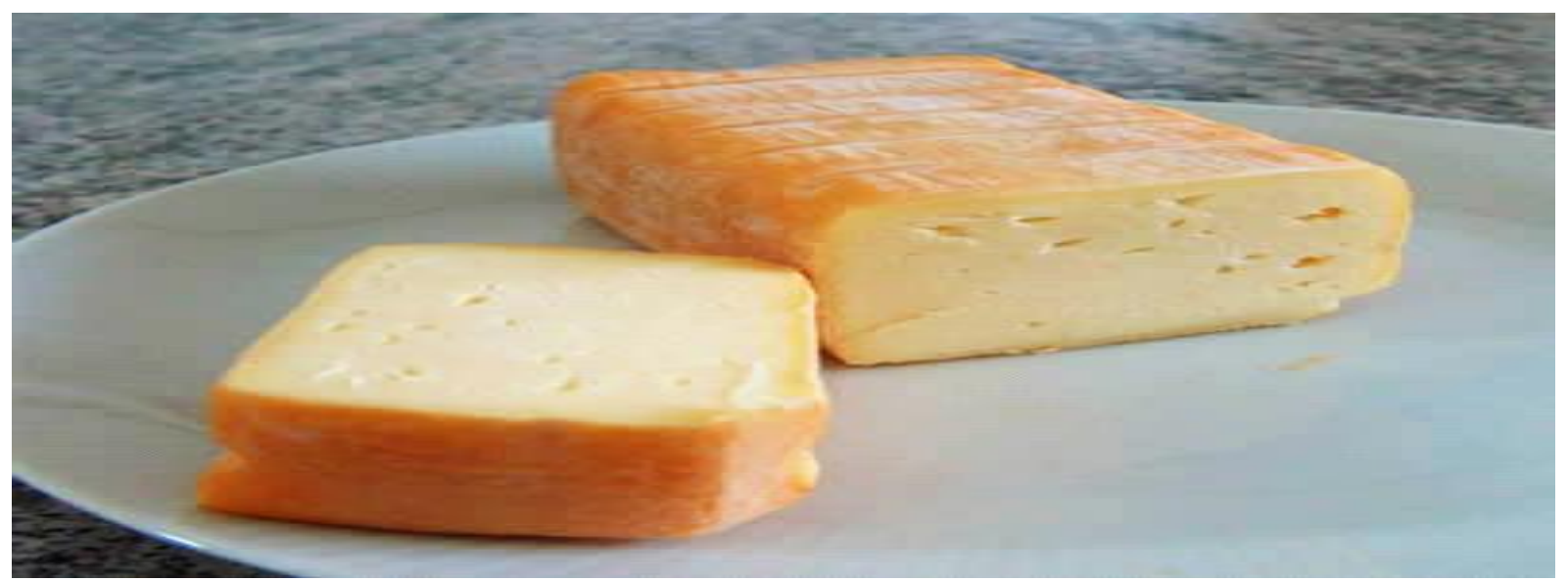

Fig.8 Gouda cheese

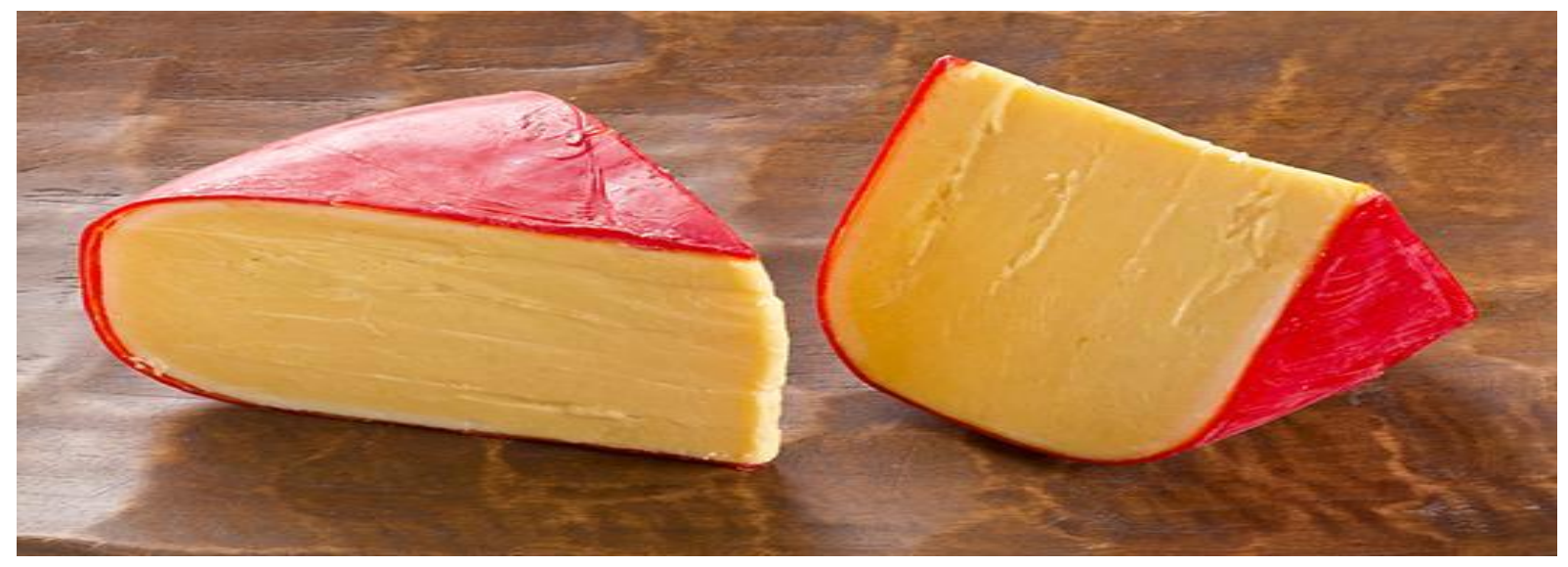

Fig.9 Camembert cheese

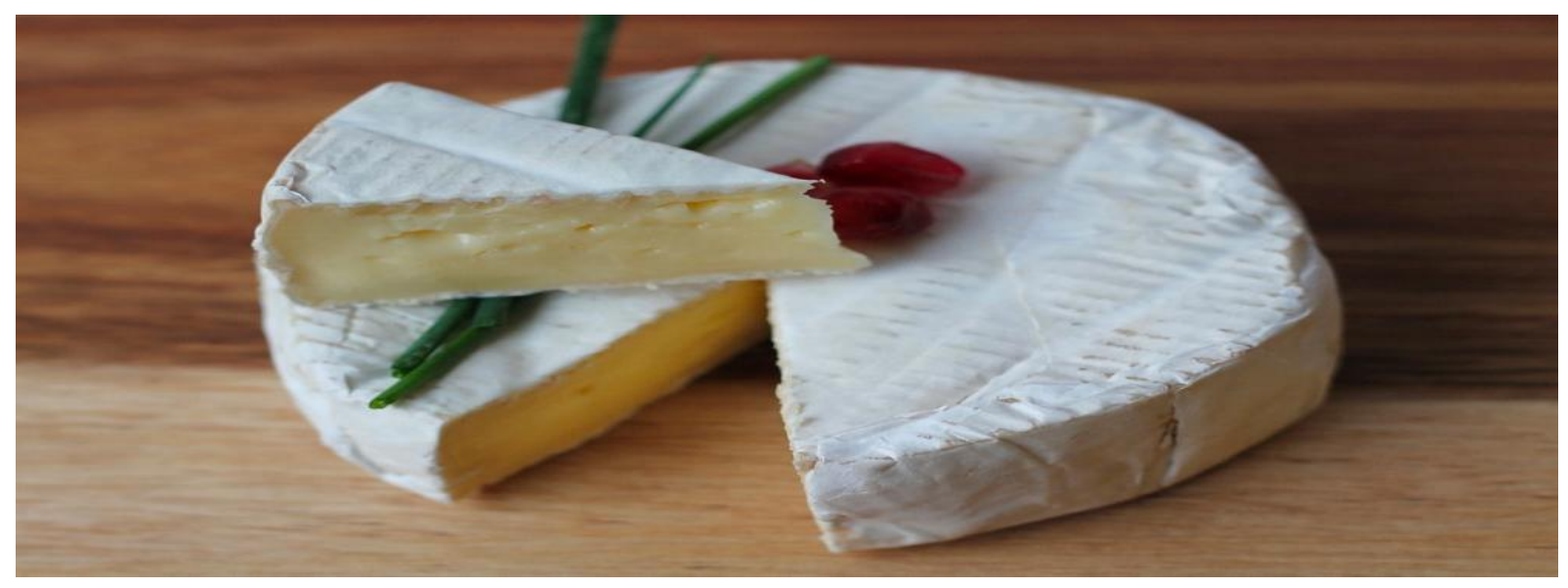


Fig.10 Chevre cheese

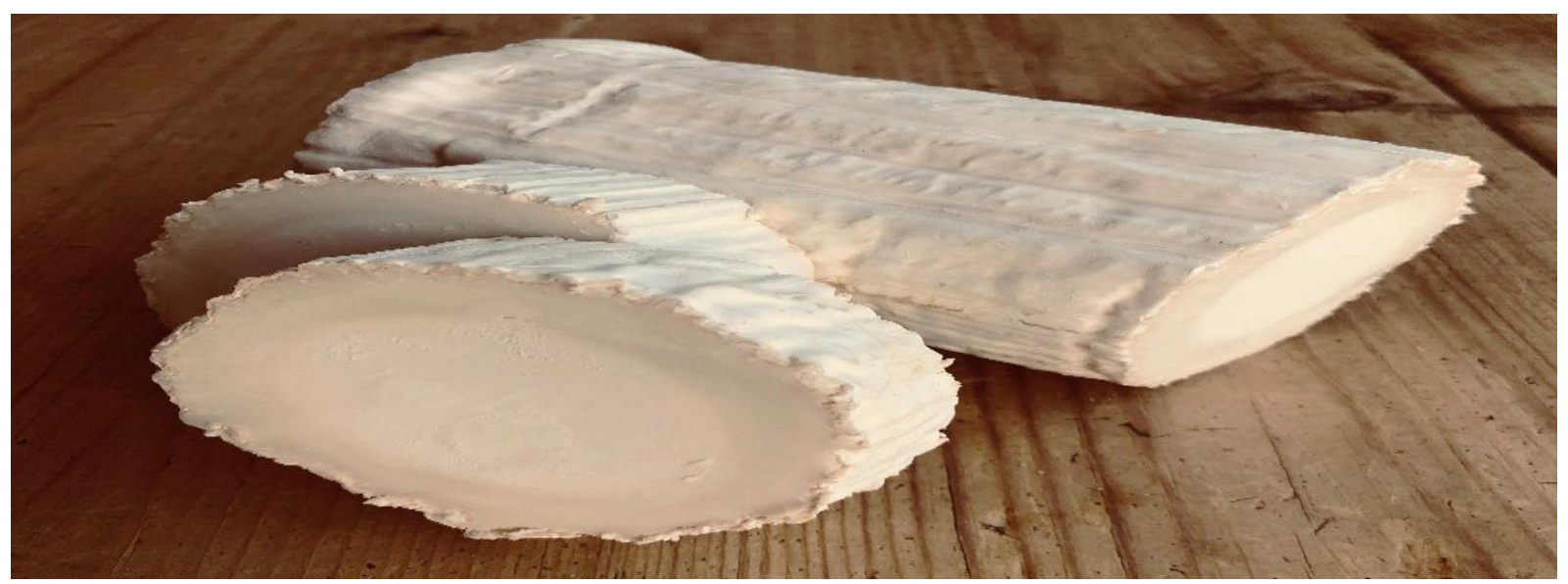

Fig.11 Monterey jack cheese

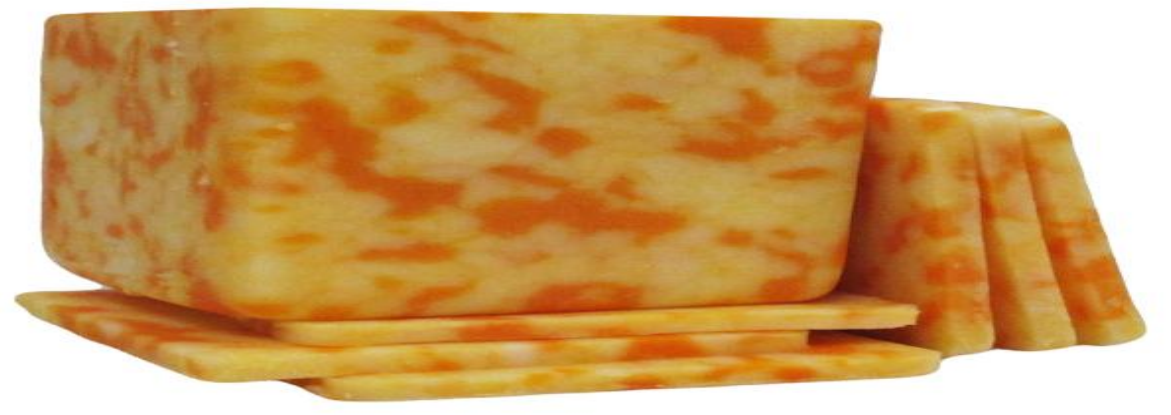

\section{Component effect on cheese flavor}

\section{Proline and carbonyl compounds}

Langsrud and Reinbold, 2016 lighten up the proline content and carbonyl compound while discussing production of swiss cheese. Butother three articles don't botherabout these two compounds. The table shows that these two components of flavor may not get its importance yet and the microbiologists should focus on these two components to enhance the flavor characteristics of cheese. The swiss cheese possessed sweet flavor due to this proline, important is how its structure interact in swiss cheese production and which part of its structure play role here.
Flavor of swiss cheese may enhanced by using low concentrations of carbonyl compounds. Since cheese flavor development may get advancement if these two components become the hottest topic for microbiologists.

\section{Lipolysis}

Lipolysis is process in which free fatty acids are produced through the hydrolysis of triglycerides that is enzyme catalyzed. It is due to lipase and microbial lipases that found in dairy products as well as in milk and causing the formation of flavor, may rancid defects. (Arnold et al., 2010) 
Malacata, 1998 and (Langsrud and Reinbold, 2016); didn't discuss lipolysis which is the hydrolytic cleavage of triglycerides but remaining two articles investigate this property. Due to combination of lipolytic enzymes free fatty acid produced, help in increase of flavor. Lipolysis may produce rancid defect.

In conclusion, cheese involves a very diverse microflora and selection of suitable strains is required for the development of required flavor. There are a lot of variety of cheeses and every cheese is different from other in flavor, texture and aroma only by the up and down of one or more composition elements and by regulating some factors influencing the components growth.Every cheese is characterized by different series of interaction between different components therefor we should have an understanding of the way these components will behave efficiently by producing high yield in less time and energy consumption. By the understanding of different microbiological techniques, there will be improvement and facilitation in the detection, isolation and identification of essential flavor compounds in specific cheese type and by this we can also enhance the controlled production of variety of cheeses

There is a cheese for every taste preference and a taste preference for every cheese (Olson et al., 1990).

\section{Acknowledgement}

Great acknowledgement is given to Prof. Dr. Sikander Ali Mughal of institute of industrial biotechnology for helpful discussion concerning the paper.

\section{References}

Abdi, R., Sheikh-Zeinoddin, M., and Soleimanian-Zad, S. (2006).
Identification of lactic acid bacteria isolated from traditional Iranian Lighvan cheese. Pakistan Journal of Biological Sciences, 9(1), 99-103.

Adda, J. (1986) Flavour of dairy products. In Developments in Food Flavours, eds G. G. Birch and M. G. Lindley, pp 151-172. Elsevier Applied Science, London

Adda, J., Gripon, J. C., and Vassal, L. (1982). The chemistry of flavor and texture generation in cheese. Food Chemistry, 9(1-2), 115-129.

Alford, J. A., and Frazier, W. C. (1950). Effect of micrococci on the development of flavor when added to Cheddar cheese made from pasteurized milk. Journal of Dairy Science, 33(2), 115-20.

Anderson, D. F., and Day, E. A. (1966). Quantitation, evaluation, and effect of certain microorganisms on flavor components of blue cheese. Journal of Agricultural and Food Chemistry, 14(3), 241-245.

Beresford, T. P., Fitzsimons, N. A., Brennan, N. L., and Cogan, T. M. (2001). Recent advances in cheese microbiology. International dairy journal, 11(4-7), 259-274.

Broadbent, J. R., Strickland, M., Weimer, B. C., Johnson, M. E., and Steele, J. L. (1998). Peptide accumulation and bitterness in Cheddar cheese made using single-strain Lactococcus lactis starters with distinct proteinase specificities. Journal of Dairy Science, 81(2), 327-337.

Cogan, T. M., and Hill, C. (1993). Cheese starter cultures. In P. F. Fox (Ed.), Cheese: Chemistry, physics and microbiology, Vol. 1 (pp. 193-255). London: Elsevier Applied Science

Cogan, T. M., Barbosa, M., Beuvier, E., Bianchi-Salvadori, B., Cocconcelli, P. S., Fernandes, I., Gomez, J., Gomez, 
R., Kalantzopoulos, G., Ledda, A., Medina, M., Rea, M. C., and Rodriguez, E. (1997). Characterization of the lactic acid bacteria in artisanal dairy products. Journal of Dairy Research, 64, 409-421

Eliskases-Lechner, F., and Ginzinger, W. (1995). The yeast flora of surfaceripened cheeses. Milchwissenschaft (Germany).

El-Soda, M.; Desmazeaud, M. J.; Aboudonia, S.; Kanal, N. Acceleration of cheese ripening by the addition of whole cells or cell free extracts from Lactobacillus casei to the cheese curd. Milchwissenschaft 1981, 36, 140-142.

Esteban, M. A., and Marcos, A. (1989). Chemical prediction of water activity in processed cheese. Journal of Dairy Research, 56(4), 665-668

Fleet, G. H. (1990). Yeasts in dairy products. Journal of applied bacteriology, 68(3), 199-211.

Folkertsma, B., Fox, P. F., and McSweeney, P. L. H. (1996). Accelerated ripening of Cheddar cheese at elevated temperatures. International Dairy Journal, 6(11-12), 1117-1134.

Fox, P. F., and Wallace, J. M. (1997). Formation of flavor compounds in cheese. Advances in Food Microbiology, 45, 17-85.

Giraffa, G. (2004) 'Studying the dynamics of microbial populations during food fermentation', FEMS Microbiology Reviews, 28(2), pp. 251-260. doi: 10.1016/j.femsre.2003.10.005

Giraffa, G. (2004) 'Studying the dynamics of microbial populations during food fermentation', FEMS Microbiology Reviews, 28(2), pp. 251-260. doi: 10.1016/j.femsre.2003.10.005

Ha, J. K., and Lindsay, R. C. (1991). Volatile branched- chain fatty acids and phenolic compounds in aged Italian cheese flavors. Journal of Food
Science, 56(5), 1241-1247.

Habibi- Najafi, M. B., Lee, B. H., and Law, B. (1996). Bitterness in cheese: a review. Critical Reviews in Food Science and Nutrition, 36(5), 397-411

HEISSERER, D. M., and IV, E. C. (1993). DETERMINATION OF THE SENSORY FLAVOR ATTRIBUTES OF AGED NATURAL CHEESE 1. Journal of Sensory Studies, 8(2), 121132.

Jana, A. H., and Mandal, P. K. (2011). Manufacturing and quality of Mozzarella cheese: A review. International Journal of Dairy Science, 6(4), 199-226

Jordan, K. N., and Cogan, T. M. (1993). Identification and growth of nonstarter lactic acid bacteria in Irish Cheddar cheese. Irish Journal of Agriculture and Food Research, 32, 47-55.

Kristoffersen, T., and Gould, I. A. (1960). Cheddar cheese flavor. II. Changes in flavor quality and ripening products of commercial Cheddar cheese during controlled curing. Journal of Dairy Science, 43(9), 1202-1215.

Langsrud, T. and Reinbold, G. W. (2016) 'Flavor Development and Microbiology of Swiss Cheese-a Review', Journal of Milk and Food Technology, 36(11), pp. 531-542. doi: 10.4315/0022-2747-36.11.531

Langsrud, T. and Reinbold, G. W. (2016) 'Flavor Development and Microbiology of Swiss Cheese-a Review', Journal of Milk and Food Technology, 36(11), pp. 531-542. doi: 10.4315/0022-2747-36.11.531

Lawrence, R. C., and Gilles, J. (1987). Cheddar cheese and related drysalted varieties. In P. F. Fox (Ed.), Cheese: Chemistry, physics and microbiology, Vol. 2 (pp. 1-44). London: Elsevier Applied Science. 
Lodics, T., and Steenson, L. (1993). Phagehost interactions in commercial mixed-strain cultures: Practical significance, a review. Journal of Dairy Science, 76, 2380-2391.

Malcata, F. X. (1998) 'Microbiological Characterization of Serra da Estrela Cheese throughout Its Appellation d' Origine Protegee Region', 61(5), pp. 601-607.

Micketts, R., and Olson, N. F. (1974). Manufacture of Mozzarella cheese by direct acidification with reduced amounts of rennet and pepsin. Journal of Dairy Science, 57(3), 273-279

Molimard, P., and Spinnler, H. E. (1996). Compounds involved in the flavor of surface mold-ripened cheeses: Origins and properties. Journal of dairy science, 79(2), 169-184

Olson, N. F. (1990). The impact of lactic acid bacteria on cheese flavor. FEMS Microbiology Reviews, 7(1-2), 131147

Patton, S. (1950). The methyl ketones of blue cheese and their relation to its flavor. Journal of Dairy Science, 33(9), 680684

R. uegg, M., and Blanc, B. (1981). Influence of water activity on the manufacture and ageing of cheese. In L. B. Rockland, and G. F. Stewart (Eds.), Water activity: Influences on food quality (pp. 791-811). New York: Academic Press

Sánchez-Palomo, E., Pérez-Coello, M. S., and Cabezas, L. (2008). Volatile composition, olfactometry profile and sensory evaluation of semi-hard
Spanish goat cheeses. Dairy Science and Technology, 88(3), 355-367.

Sánchez-Palomo, E., Pérez-Coello, M. S., and

Cabezas, L. (2008). Volatile composition, olfactometry profile and sensory evaluation of semi-hard Spanish goat cheeses. Dairy Science and Technology, 88(3), 355-367.

Steffen, C., Eberhard, P., Bosset, P. O., and Rüegg, M. (1993). Swiss-type varieties. Ch. 3 in Cheese: Chemistry, Physics and Microbiology-Vol. 2, PF Fox

Visser, F. M. W. Contribution of enzymes from rennet, starter bacteria and milk to proteolysis and flavour development in Gouda cheese. 3. Protein breakdown: Analysis of the soluble nitrogen and amino acid nitrogen fractions. Neth. Milk Dairy J. 1977, 31, 210-239.

Weber, F., and Ramet, J. P. (1987). Comparative technology of the ripening methods of different types of cheese.

Whetstine, M. C., Karagul-Yuceer, Y., Avsar, Y. K., and Drake, M. A. (2003). Identification and quantification of character aroma components in fresh Chevre-style goat cheese. JOURNAL OF FOOD SCIENCE-CHICAGO-, 68(8), 2441-2447.

Woo, A. H., Kollodge, S., and Lindsay, R. C. (1984). Quantification of major free fatty acids in several cheese varieties. Journal of Dairy Science, 67(4), 874878.

\section{How to cite this article:}

Rida Malik, Maria Tahir, Nida Pervaiz and Sikander Ali. 2020. Flavor Development in Various Forms of Cheese. Int.J.Curr.Microbiol.App.Sci. 9(01): 2497-2511. doi: https://doi.org/10.20546/ijcmas.2020.901.284 